\title{
Uji Formulasi Pupuk Hayati Padat Berbasis Azolla Terhadap Populasi dan Fungsional Mikroba Tanah Menguntungkan
}

\author{
Mieke Rochimi Setiawati', Maya Damayanti' ${ }^{1}$, Diyan Herdiyantoro', \\ Pujawati Suryatmana ${ }^{1}$, dan Fiqriah Hanum Khumairah ${ }^{2}$ \\ ${ }^{1}$ Departemen Ilmu Tanah dan Sumberdaya Lahan Fakultas Pertanian, Universitas Padjadjaran \\ ${ }^{2}$ Alumni Program Studi Agroteknologi, Fakultas Pertanian, Universitas Padjadjaran \\ Jl. Raya Bandung Sumedang Km 21 Jatinangor
}

Korespondensi: m.setiawati@unpad.ac.id

\begin{abstract}
Inorganic fertilizer is a very important agricultural input to increase agricultural production. Uncalculated and continuous application of inorganic fertilizers will lead to the reduction of soil fertility and degradation of environmental quality. Therefore, a strategy is needed to support the environmental sustainability in agriculture. One of the efforts is through the production of biofertilizer and organic fertilizer from local resources. Organic fertilizer for rice plants can be made by utilizing the local water fern, Azolla pinnata. A. pinnata can be applied on rice fields as green manure by directly placing it into the soil or spread on the surface of rice fields. Organic fertilizer that made from Azolla will be more advantageous because it can be applied with biofertilizer. This study aimed to determine the formulation of Azolla based solid biofertilizer that can support the growth of functional microbial population based on the Agriculture Ministry (Permentan) standard number 70/2011. The design of the study method used was Completely Randomized Design with six replications. The treatments used were inoculant starter with 3\% molasses, 3\% molasses $+10 \%$ rice wash water, $3 \%$ molasses $+1 \%$ yeast extract, and $3 \%$ molasses $+10 \%$ rice wash water $+1 \%$ yeast extract. The results of this study showed that Azolla-based solids fertilizer with starter formula $3 \%$ inoculant molasses $+10 \%$ rice water $+1 \%$ yeast extract have the population of Azotobacter, Azospirillum, endophytic bacteria and phosphate solubilizing microbe were greater than $10^{8} \mathrm{cfu} / \mathrm{g}$ dry weight. Functional microbial of solids fertilizers in all formulas used do not show the difference on inhabiting in the N-free media or Pikovskaya selective media.
\end{abstract}

Keywords: Azolla pinnata, formulation, biofertilizer, organic fertilize

\section{PENDAHULUAN}

Pupuk anorganik atau pupuk buatan pabrik merupakan input pertanian yang sangat penting untuk meningkatkan produksi pertanian. Petani cenderung menggunakan pupuk anorganik dengan dosis lebih besar dari dosis anjuran dengan anggapan akan menghasilkan panen lebih besar dari panen sebelumnya. Penggunaan pupuk anorganik yang tidak sesuai dengan dosis anjuran dan terus menerus diberikan akan berdampak pada penurunan kesuburan tanah dan kerusakan lingkungan. Oleh karena itu diperlukan strategi dalam mengatasi kerusakan lingkungan untuk menunjang pertanian yang berkelanjutan. Salah satu usaha dalam memenuhi kebutuhan pupuk untuk tanaman adalah memproduksi pupuk hayati dan pupuk organik dari sumberdaya lokal.

Pupuk organik untuk tanaman padi dapat memanfaatkan potensi sumberdaya lokal seperti jerami, bahan hijauan, dll. Sumberdaya lokal ini sering juga dimanfaatkan sebagai pakan ternak sehingga tujuan pemanfaatan bahan organik ini tidak tercapai. Salah satu alternatif lainnya adalah memanfaatkan tanaman air lokal yaitu tanaman paku air Azolla pinnata yang hidup di permukaan tanah sawah.

Pemanfaatan A. pinnata sebagai pupuk organik lebih menguntungkan karena mengandung nitrogen lebih tinggi daripada bahan organik lainnya. A. pinnata bersimbiosis dengan sianobakteria Anabaena azolla penambat $\mathrm{N}_{2}$ sehingga bila 
dikomposkan akan menghasilkan pupuk organik yang kaya nitrogen (mengandung 3-5 $\%$ N). Berdasarkan bobot keringnya Azolla pinnata mengandung 0,5\% - 0,9\% N (1,96$5,30 \%), P(0,16-1,59 \%)$, Si $(0,16-3,35 \%), C a$ (0,31-5,97\%), Fe (0,04-0,59\%), Mg (0,220,66\%) (Mamduh, 2013).

Azolla pinnata dapat diberikan pada lahan sawah sebagai pupuk hijau dengan cara langsung dibenamkan ke dalam tanah atau ditebarkan di permukaan sawah kemudian dibenamkan ke dalam tanah pada saat pembuangan gulma. Pembuatan kompos pupuk organik padat berbasis Azolla akan lebih menguntungkan dibandingkan langsung dibenamkan sebagai pupuk organik. Kompos Azolla dapat digunakan sebagai bahan pembawa (carrier) mikroba yang menguntungkan untuk padi sawah dengan cara dikombinasikan dengan mikroba menguntungkan seperti mikroba penambat $\mathrm{N}$ dan pelarut fosfat. Produk yang dihasilkan dari kombinasi antara kompos Azolla dengan mikroba yang menuntungkan adalah pupuk hayati padat berbasis Azolla.

Kualitas pupuk hayati padat sangat ditentukan oleh populasi mikroba fungsional yang ada di dalam pupuk hayati padat tersebut. Menurut peraturan Menteri Pertanian tahun 2011 nomor 70, syarat jumlah populasi mikroba fungsional di dalam pupuk hayati padat harus mengandung minimal $10^{7} \mathrm{cfu} / \mathrm{g}$ media pembawa. Bila populasi mikroba fungsional dibawah populasi yang disyaratkan permentan akan menyebabkan efektivitas pupuk hayati tersebut tidak optimal.

Populasi mikroba fungsional yang tinggi pada media pembawa pupuk hayati padat dapat tercapai apabila starter yang diberikan kedalam pupuk hayati padat mengandung populasi yang tinggi. Starter inokulan dapat diformulasikan sedemikian rupa dengan cara memperkaya dengan menggunakan tambahan berbagai nutrisi yang dapat mempercepat pertumbuhan mikroba misalnya dengan menambahkan yeast ekstrak/ekstrak ragi, air cucian beras yang kaya protein, vitamin dan mineral. Penambahan nutrisi dari air cucian beras ke dalam formulasi pupuk hayati padat diharapkan dapat meningkatkan populasi mikroba fungsional sesuai aturan permentan. Penelitian ini bertujuan menentukan formulasi pupuk hayati padat berbasis Azolla yang menghasilkan populasi mikroba fungsional yang masuk standar mutu Permentan nomor 70/2011.

\section{METODE PENELITIAN}

Penelitian ini dilakukan di Lab Biologi Tanah Fakultas Pertanian Unpad. Bahan yang digunakan adalah media molase $3 \%$, air cucian peras yang pertama dan kedua dari 1 kg beras, ekstrak ragi komersial (fermipan), akuades, dan bahan untuk menentukan populasi mikroba penambat $\mathrm{N}$ (Ashby, Okon, $\mathrm{JNFb}$ ) dan bakteri pelarut $\mathrm{P}$ (media Pikovskaya). Alat yang digunakan adalah peralatan gelas untuk menentukan populasi mikroba dan coloni counter.

Perlakuan percobaan yang digunakan adalah jenis starter inokulan yang terdiri atas: molase $3 \%$, molase $3 \%+$ air cucian beras 10 $\%$, molase $3 \%+$ ekstrak ragi $1 \%$, dan molase $3 \%+$ air cucian beras $10 \%$ + ekstrak ragi $1 \%$.

Starter inokulan yang telah dipersiapkan disemprotkan pada carrier/bahan pembawa kompos azolla yang sudah disterilkan sebanyak $20 \%(\mathrm{v} / \mathrm{w})$ dari total berat bahan pembawa. Pupuk hayati padat tersebut diinkubasikan selama delapan minggu kemudian dihitung total populasi mikroba serta aktivitas fungsionalnya. Perlakuan di atas diulang lima kali, rancangan perlakuan yang digunakan adalah Rancangan Acak Lengkap.

\section{HASIL DAN PEMBAHASAN}

\subsection{Populasi Mikroba Fungsional}

Pengkayaan starter inokulan dengan pemberian air cucian beras, ekstrak ragi dan gabungannya mengakibatkan adanya peningkatan populasi bakteri Azotobacter, 
Azospirillum, endofitik dan bakteri pelarut fosfat. Pemberian air cucian beras dan ekstrak ragi pada strarter inokulan menghasilkan populasi bakteri fungsional yang tertinggi (Tabel 1). Kandungan air cucian beras antara lain karbohidrat, nitrogen, fosfor, kalium, magnesium, sulfur, besi, Vitamin B1. Limbah air cucian beras yang kaya akan nutrisi juga dapat digunakan sebagai pupuk organik cair pengganti pupuk kimia pada beberapa tumbuhan (Wulandari dkk, 2012).
Penambahan air cucian beras pada media pertumbuhan dapat meningkatkan sumber nutrisi karbohidrat dan nitrogen. Sumber nutrisi ini dapat digunakan sebagai sumber energi dan membentuk biomassa selnya sehingga mikroba tersebut dapat bermultiplikasi dengan cepat apabila ada. Kandungan mineral dan vitamin dapat digunakan untuk meningkatkan aktivitas metabolismenya karena unsur hara tersebut diperlukan untuk kerja enzim.

Tabel 1 Pengaruh jenis starter inokulan terhadap populasi mikroba fungsional pada pupuk hayati padat berbasis Azolla

\begin{tabular}{|c|c|c|c|c|}
\hline \multirow[b]{2}{*}{ Jenis starter inokulan } & \multicolumn{4}{|c|}{ Populasi bakteri (cfu/g) pada minggu ke-8 } \\
\hline & $\begin{array}{c}\text { Azotobacter } \\
\left(10^{7}\right)\end{array}$ & $\begin{array}{l}\text { Azospirillum } \\
\quad\left(10^{7}\right)\end{array}$ & Endofit $\left(10^{8}\right)$ & $\begin{array}{l}\text { BPF } \\
\left(10^{7}\right)\end{array}$ \\
\hline $\mathrm{A}=$ molase $3 \%$ & 3,95 a & $1,01 \mathrm{a}$ & $1,54 \mathrm{a}$ & $1,29 \mathrm{a}$ \\
\hline $\mathrm{B}=$ molase $3 \%+$ air cucian beras $10 \%$ & $4,08 \mathrm{a}$ & $2,44 \mathrm{~b}$ & $2,24 \mathrm{a}$ & $1,42 \mathrm{a}$ \\
\hline $\mathrm{C}=$ molase $3 \%+$ ekstrak ragi $1 \%$ & $8,04 \mathrm{~b}$ & $3,19 \mathrm{~b}$ & $4,04 \mathrm{~b}$ & $2,85 \mathrm{a}$ \\
\hline $\begin{array}{l}\mathrm{D}=\text { molase } 3 \%+\text { air cucian beras } 10 \% \\
+ \text { ekstrak ragi } 1 \%\end{array}$ & $12,52 \mathrm{c}$ & $11,03 \mathrm{c}$ & $11,38 \mathrm{c}$ & $11,61 \mathrm{~b}$ \\
\hline
\end{tabular}

Menurut Informasi Gizi Kementerian Kesehatan Republik Indonesia, kandungan ragi mengandung berbagai vitamin mineral karbohidrat dan protein. Vitamin yang dikandungnya lebih beragam diantaranya vitamin A, B1, dan C. Untuk pertumbuhan dan peningkatan populasi mikroba, vitamin diperlukan sebagai precursor untuk kerja enzim didalam proses metabolismenya. Penambahan ragi pada starter inokulan dapat meningkatkan populasi bakteri fungsional.

Penambahan air cucian beras dan ekstrak ragi dapat melengkapi kebutuhan nutrisi dari media cair molase karena kekurangan vitamin dan mineral di dalam larutan molase $3 \%$ dapat disuplai dari air cucian beras dan ekstrak ragi. Molase adalah hasil samping yang berasal dari pembuatan gula tebu (Saccharumofficinarum). Tetes tebu berupa cairan kental dan diperoleh dari tahap pemisahan Kristal gula. Molase tidak dapat lagi dibentuk menjadi sukrosa namun masih mengandung gula dengan kadar tinggi 50$60 \%$, asam amino dan mineral Brown (2003).

Media cair molase $3 \%$ masih mengandung sedikit vitamin, kekurangan vitaminnya dapat dipasok dari kombinasi air cucian beras dan ekstrak ragi, sehingga starter dengan kombinasi molase, air cucian beras dan ekstrak ragi menghasilkan populasi bakteri Azotobacter, Azospirillum, Endofitik dan Bakteri Pelarut Fosfat yang tertinggi.

Pada saat starter inokulan pupuk hayati diinokulasikan pada kompos Azolla yang befungsi sebagai carrier atau bahan pembawa mikroba fungsional maka kebutuhan nutrisi mikroba di dalam bahan pembawa telah terpenuhi dari starter dan dari hasil dekomposisi kompos azolla. Persyaratan bahan yang dapat digunakan sebagai bahan pembawa pupuk hayati padat antara lain harus bisa menjamin keberlangsungan hidup dan efektivitas inokulan yang ada di dalamnya 
dari gangguan biotik maupun abiotik (Van Veen, et al., 1997 dalam El-Fattah et al., 2013).

\subsection{Aktivitas Mikroba Fungsional}

Syarat baku mutu yang harus dipenuhi oleh suatu pupuk hayati agar fungsi mikroba yang terkandung dalam pupuk hayati dpt memberikan pengaruh positif terhadap tanaman yang diinokulasi salah satunya adalah aktivitas fungsional mikroba yang dijadikan inokulan. Aktivitas fungsional mikroba pada pupuk hayati diantaranya adalah menambat nitrogen dari udara bebas dan melarutkan fosfat dari fosfat yang sukar larut (Permentan, 2011).

Berdasarkan hasil uji aktivitas mikroba fungsional semua mikroba penambat $\mathrm{N}$ dan pelarut fosfat menunjukkan aktivitas fungsionalnya yang positif (Tabel 2). Mikroba penambat $\mathrm{N}$ yang digunakan pada percobaan ini dapat hidup pada media bebas $\mathrm{N}$ (JNFb). Mikroba yang tumbuh pada media bebas $\mathrm{N}$, kebutuhan dasar $\mathrm{N}$ dipasok dari hasil penambatan $\mathrm{N}_{2}$ dari udara. Sehingga bagi bakteri yang tidak mempunyai enzim nitogenase yang berfungsi untuk menambat $\mathrm{N}$ dari udara akan tidak dapat tumbuh pada media tersebut.

Tabel 2 Pengaruh jenis starter inokulan terhadap aktivitas mikroba fungsional pada pupuk hayati padat berbasis Azolla

\begin{tabular}{ccccc}
\hline \multirow{2}{*}{ Parameter } & \multicolumn{2}{c}{ Standar Mutu Menurut Jenis Bahan Pembawa } & \multirow{2}{*}{ Metode Pengujian } \\
\cline { 2 - 4 } & Tepung/Serbuk & Granul/Pelet & Cair & \\
\hline Fungsional : & Positif & Positif & Positif & Media bebas N, Media \\
$\begin{array}{l}\text { a. Penambat N } \\
\text { b. Pelarut P }\end{array}$ & Positif & Positif & Positif & $\begin{array}{c}\text { Pikovskaya } \\
\text { Perlakuan : }\end{array}$ \\
A & Positif & & & Media bebas N \\
B & Positif & - & - & Media Pikovskaya \\
& Positif & & & Media bebas N \\
Cositif & Positif & - & - & Media Pikovskaya \\
& Positif & - & - & Media bebas N \\
& Positif & & & Media Pikovskaya \\
D & Positif & - & - & Media bebas N \\
& & & & Media Pikovskaya \\
\hline
\end{tabular}

Bakteri penambat $\mathrm{N}$ non simbiotik seperti Azotobacter dan Azospirillum dan bakteri Endofitik yang simbiotik hidup di dalam jaringan dengan tanaman menunjukkan respon yang sama di dalam pertumbuhannnya di dalam media bebas $\mathrm{N}$ yaitu mampu tumbuh dengan baik pada media bebas N. Perbedaannya bakteri endofitik membentuk cincin bening dibawah permukaan agar tegak semisolid JNFb. Fungsi bakteri endofitik pada pupuk hayati lebih Bakteri Endofitik diketahui dapat mengikat hara nitrogen dan melarutkan fosfat sehingga mengurangi pengggunaan pupuk buatan (Pedraza et al.,2004 dalam Gusmaini dkk,
2013), memproduksi fitohormon (Puente, et al., 2009 dalam Gusmaini dkk, 2013).

Aktivitas bakteri pelarut fosfat juga harus mempunyai kemampuan melarutkan fosfat tidak laru di dalam media tersebut. Didalam media Pikovkaya terdapat fosfat tidak latut dalam bentuk $\mathrm{Ca}_{3}\left(\mathrm{PO}_{4}\right)_{2}$. Bakteri pelarut fosfat akan mengeluarkan asam-asam organik dalam melarutkan fosfat tidak larut menjadi $\mathrm{H}_{2} \mathrm{PO}_{4}{ }^{-}$ yang terlarut dan tersedia bagi bakteri tersebut. Aktivitas melarutkan $\mathrm{P}$ tidak tersedia ditandai dengan munculnya zona bening di sekitar koloni bakteri pelarut fosfat. Menurut Illmer et. al. (1995), mekanisme pelarutan fosfat secara kimia merupakan 
mekanisme pelarutan fosfat utama yang dilakukan oleh mikroorganisme. Ginting dkk. (2012) menyatakan bahwa mikroorganisme tersebut mengekskresikan sejumlah asam organik berbobot molekul rendah. Meningkatnya asam-asam organik tersebut diikuti dengan penurunan $\mathrm{pH}$. Penurunan $\mathrm{pH}$ juga dapat disebabkan karena terbebasnya asam sulfat dan nitrat pada oksidasi.

\section{KESIMPULAN}

Pupuk hayati padat berbasis Azolla dengan formula molase $3 \%+$ air cucian beras $10 \%+$ ekstrak ragi $1 \%$ menghasilkan populasi Azotobacter, Azospirillum, bakteri endofitik dan mikroba pelarut fosfat lebih besar dari $10^{8} \mathrm{cfu} / \mathrm{g}$ bahan. Mikroba fungsional pupuk hayati padat pada semua formula yang digunakan tidak menunjukkan perbedaan yaitu positif menambat $\mathrm{N}$ di dalam media bebas $\mathrm{N}$ atau media selektif Pikovskaya.

\section{DAFTAR PUSTAKA}

Brown, R.C. 2003. Bioreneweble Resources : Engineering New Product from Agriculture. Iowa State Press, USA.

El-Fattah, D.A.A., W. E. Eweda, M. S. Zayed, M. K. Hassanein. 2013. Effetct of carrier materials, sterilization method and storage temperature on survival and biological activities of Azotobacter chroococcum inoculant. Annals of Agricultural Science 58 (2): 111 118.

Ginting, R.C.B., R. Saraswati, dan E. Husen. 2012. Mikroorganisme pelarut fosfat. Dalam Simanungkalit, R.D.M (eds). Pupuk Organik dan Pupuk Hayati. Balai Besar Penelitian dan Pengembangan Sumberdaya Lahan Pertanian. Hal: 141 - 158.

Gusmaini, S. A. Aziz, A. Munif, D. Sopandie, dan N. Bermawie. 2013. Potensi bakteri endofit dalam upaya meningkatkan pertumbuhan, produksi, dan kandungan andrografolid pada tanaman sambiloto. Jurnal Littri 19 (4): 167-177.

Illmer, P., A. Barbato, and F. Schinner. 1995. Solubilization of hardly-soluble AlPO4 with P-solubilizing microorganisms. Soil Biology and Biochemistry. 24(3): 265-270.

Mamduh, A. 2013. Pengaruh Pemberian Pupuk Azolla pinnata Terhadap Kandungan Klorofil Pada Dunaliella salina. Fakultas Perikanan dan Kelautan, Universitas Airlangga. Skripsi.

Permentan. 2011. Peraturan Menteri Pertanian No.70/Permentan/SR.140/10/2011.

Wulandari, C. G. M, S. Muhartini, dan S. Trisnowati. 2012. Pengaruh air cucian beras merah dan beras putih terhadap pertumbuhan dan hasil selada (Lactuca sativa L.). Vegatalika 1(2): $24-35$. 